\title{
SALAFISM, STATE RECOGNITION AND LOCAL TENSION: \\ New Trends in Islamic Education in Lombok
}

\author{
Saparudin \\ State Institute of Islamic Studies (IAIN) Mataram \\ Email: s_apank@yahoo.co.id
}

\begin{abstract}
This paper explores the role of Salafi formal schools in the increasing influence and proliferation of Salafism in Lombok, East Indonesia, alongside the impacts of this process on educational culture and broader social contexts. Despite intense resistance from, and even violence by, traditionalist mainstream groups, the Salafi movement has developed steadily. This paper argues that the growth of Salafism in Lombok is influenced by contextualizing of proliferation strategies by integrating into Indonesian national education system and selecting of the greater Islamic traditions, rather than ideological and financial support from the Middle East, as it has been highlighted in previous studies and literature. By establishing officially certified schools and formal recognitions from the Indonesian government, the Salafi schools have found a way to successfully recruit a new young generation of Muslims in Lombok and beyond.
\end{abstract}

Keywords: Salafi, bid'ah, recognition, tension, education, Lombok

DOI: http:/ / dx.doi.org/10.20414/ujis.v21i1.1188

\section{Introduction}

Lombok has become the longstanding base for traditionalist Islam, Nabdlatul Ulama and Nabdlatul Wathan. These are the largest Islamic groups in the area which emphasize a madhbab approach, Sufism, as well as incorporating aspects of local culture and local tradition in their religious expression. Religious activities such as visiting graves (ziarah kubur), celebrating Maulid (Prophet's birthday), practices of tablilan (prayer ritual for the deceased) and other local religious rituals are key features of traditionalist Islam in Lombok as well as in Indonesia. This traditional 
Islamic hybridity is so common that it has become a part of daily life in Lombok, in which religion and culture deeply fused together.

Recently, the mainstream position of traditionalist Islam in Lombok has been challenged by the growing influence of Salafism. Unlike the traditionalists, Salafists promote what they call the manhaj salaf (the methodology of the early pious Muslim generation/companion) which claims status as an authentic understanding or 'pure' form of Islam. Its goal is a purification of contemporary understandings and practices of Islam in line with Salafist interpretation ${ }^{1}$ including the madhbab and Sufism. Salafists believe that contemporary Islam has been corrupted by local beliefs and traditions, and elements of hybridity that traditionalists celebrate should be removed. ${ }^{2}$ Salafists state that their tradition is based directly from the Qur'an, Sunnah (prophetic tradition), and the earliest generations of Muslims known as the al-salaf al-sālih (righteous predecessors) which includes Prophet's Companions. ${ }^{3}$ Salafi preachers condemn all religious activities not mentioned in the Qur'an and Prophetic Tradition as shirik and bid'ah, which should be eradicated. In practical terms, this involves opposing widespread forms of Islamic ritual long celebrated by Lombok's Sasak people who express elements of culture and local tradition.

The differences between religious doctrines and practices between Salafists and mainstream Muslim groups have been a major source of contestation and conflict in Lombok and have led to the growth of prejudice against the Salafists. Abdul Aziz viewed Salafi movement as a new group which has an opposite perspective to other Islamic scholars and the local culture and traditions. Thus, the Salafism should be avoided by mainstream groups. ${ }^{4}$ The different perspective has fuelled tension, discord

1'Abd al-Salām al-Sihīmīy, Kun Salafizyan 'Alā al-Jaddah (Madinah alNabawiyah, 1423), 72-73.

2Nāṣir bin 'Abd al-Karīm al-Aql, Islämiyyah Lā Wabäbiyyah (Saudi: Dār al-Fadịlah, 2007), 35.

3al-Sihīmìy, Kun Salafyyyan, 72-73.

${ }^{4}$ Abdul Aziz Sukarnadi, Perisai Ke-Aswaja-an Nabdlatul Wathan Membedab 17 Literatur Anti Wababi Rekomendasi Pendiri NW (Yogyakarta: Samudera Biru, 2016); Abdul Aziz Sukarnadi, Di Bawah Lindungan Rasulullah Menyibak Tirai Keagungan Sang Manusia Cahaya (Yogyakarta: Aswaja Pressindo, 2015). 
and even conflict among local Muslims, including rupturing family relationships. Since 2004 to 2015 there were at least 12 conflicts among Lombok Muslims in which Salafists were a focus as studies. ${ }^{5}$ Alvi also claims that the spread of intra-Islamic violence and terrorism in some countries was caused by the strengthening of the Salafi extremist Wahhabi ideology. ${ }^{6}$

Despite strong resistance from mainstream groups, the Salafi movement in Lombok has been growing steadily over the last few decades. In its first decade, from 1990 to 2000, not many people pay attention to its presence or its doctrines, and there was very little growth in the movement. But in the last fifteen years, from around 2000 to 2016 Salafism has had significant growth. It can be seen in the increasing number of Salafi mosques and schools being established and the growing number of students at both the Abu Hurairah and Assunnah schools - the two largest Salafi schools in Lombok, located in Mataram and East Lombok. In 2016, the Abu Hurairah School had 2,309 students, $^{7}$ while the Assunnah School has 640 students. ${ }^{8}$ The condition leads to the key research question addressed here: Why is Salafism becoming more and more influential in Lombok despite strong resistance from the mainstream groups? What are the main factors involved in strengthening Salafism on the island?

${ }^{5}$ Murdianto and Azwandi, "Dakwah dan Konflik Sosial Jama'ah Salafi di Gunungsari Lombok Barat," Jurnal Penelitian Keislaman 9, no. 2 (2013); Faizah, "Pergulatan Teologi Salafi dalam Maenstream Keberagamaan Masyarakat Sasak," Ulumuna 16, no. 2 (December 2012): 393-399; Nuhrison M. Nuh and Ahmad Syafi'i Mufid, "Kelompok Salafi di Kabupaten Lombok Barat," in Kasus-Kasus Aliran/Paham Kegamaan Aktual di Indonesia (Jakarta: Balitbangdiklat Depag, 2009); Saparudin, Pemutusan Hubungan Keluarga Berdasarkan Afiliasi Lembaga Keagamaan di Lombok Timur, Laporan Penelitian Dosen Muda (DP2M Dikti, 2007), 60-75.

'Hayat Alvi, "The Diffusion of Intra-Islamic Violence and Terrorism: The Impact of the Proliferation of Salafi/Wahabi Ideologies," Middle East Review of International Affairs 18, no. 2 (Summer 2014): 38.

7Ponpes Abu Hurairah, Dokumen Jumlah Siswa/Santri 2016/ 2017.

8Ponpes Assunnah, Dokumen Jumlah Siswa/Santri 2015/2016. 
The existing literature surrounding Salafism provide some explanations for its growth. Some scholars such as Chaplin, ${ }^{9}$ Liow, ${ }^{10}$ Meuleman, ${ }^{11}$ and Noorhaidi, ${ }^{12}$ argue that the international support from Saudi Arabia and other Middle Eastern countries are influential to the global growth of Salafism. Secondly, Liow's findings in Thailand ${ }^{13}$ and Wiktorowicz's in Jordan ${ }^{14}$ suggest that the Salafi movement typically promotes Salafism through non-formal education. Conventionally, Salafists keep their distance from the state and rely instead on informal networks with Saudi Arabia and Kuwait. Thirdly, by its theological and social doctrines, some studies such as Wright in Africa, ${ }^{15}$ Liow in Thailand, ${ }^{16}$ Noorhaidi in Indonesia, ${ }^{17}$ and Wiktorowicz in Jordan, ${ }^{18}$ show that Salafi

${ }^{9}$ Chris Chaplin, "Imagining the Land of the Two Holy Mosques: The Social and Doctrinal Importance of Saudi Arabia in Indonesian Salafi Discourse," Austrian Journal of South-East Asian Studies 7, no. 2 (December 2014): 217-236.

10 Joseph Chinyong Liow, "Muslim Identity, Local Networks, and Transnational Islam in Thailand's Southern Border Provinces," Modern Asian Studies 45, no. 6 (2011): 1383-1421.

11Johan Meuleman, "Dakwah, Competition for Authority, and Development," Bijdragen tot de taal-, land- en volkenkunde / Journal of the Humanities and Social Sciences of Southeast Asia 167, no. 2-3 (January 2011): 236-269.

12Noorhaidi Hasan, "The Salafi Madrasas of Indonesia," in The Madrasa in Asia Political Activism and Transnational Lingkages, ed. Farrish Noor, Yoginder Sikand, and Martin van Bruinessen (Amsterdam: Amsterdam University Press, 2007).

13Liow, "Muslim Identity," 383-421.

${ }^{14}$ Quintan Wiktorowicz, "The Salafi Movement in Jordan," International Journal of Middle East Studies 32, no. 2 (May 2000): 219-240.

15Zachary Wright, "Salafi Theology and Islamic Orthodoxy in West Africa," Comparative Studies of South Asia, Africa and the Middle East 35, no. 3 (January 2015): 647-656.

16Liow, "Muslim Identity."

${ }^{17}$ Hasan, "The Salafi”; Noorhaidi Hasan, "Salafi Madrasahs and Islamic Radicalism in Post-New Order Indonesia," in Islamic Studies and Islamic Education in Contemporary Southeast Asia, ed. Kamaruzzaman and Patrick Jory (Kuala Lumpur: Yayasan Ilmuan, 2011).

${ }^{18}$ Quintan Wiktorowicz, "Anatomy of the Salafi Movement," Studies in Conflict \& Terrorism 29, no. 3 (2006): 207-239. 
movement is an exclusive and puritan group that rejects the incorporation of local tradition and any notion of flexibility in Islamic practices.

Scholars above have often neglected the important of contemporary contextual dynamics and local factors in the Salafi movement. The growth of Salafism in Lombok is not simply influenced by the Middle East ideological and financial support. The state official recognition to Salafi-affiliated schools has contributed to its development. In Lombok, the Salafi movement is not distancing itself from the state system, as Wiktorowicz and Liow described. Instead, it actively involves in integrating Salafi Schools into the Indonesian national education system. Noorhaidi has argued that such integration forms strategy to avoid being labeled a "terrorist" group. ${ }^{19}$ However, my fieldwork suggests that these arguments may exaggerate the local significance of international anti-Salafi stereotypes. Furthermore, Noorhaidi does not explain how Salafi schools have leveraged this form of the state recognition to promote their ideology. Salafi is also typically portrayed as wholly opposed local tradition. However, in my case study, Salafi groups have selectively incorporated broader Islamic traditions rather than local traditions into promoting its ideology. The incorporation can be seen in their active involvement in Islamic competitions such as memorizing Qur'an, preaching, and Arabic speech competitions.

This paper argues that the growth of Salafism in Lombok is influenced by contextualising of proliferation strategies by integrating the Salafi schools into the Indonesian national education system and selecting of the broader Islamic traditions, rather than ideological and financial Middle East support, which are well-known factors cited by a range of Indonesian commentators and often highlighted in existing literature. By establishing certified national schools endorsed by the Indonesian government, the Salafi group has found means of recruiting a new young generation of Muslims in Lombok and beyond successfully. Moreover, in becoming recognized

19Hasan, "The Salafi." 
formally in the state system, Salafi religious schools began to receive official invitations to Arabic speech, preaching (da'wab) and Qur'an memorizing competitions from regional and national levels of government, which this kind of the great Islamic traditions. This paper explores the role of the Salafist formal school in the increasing influence of Salafism regarding its doctrine and proliferation in Lombok, East Indonesia. Furthermore, I consider the implications of this process within the educational culture and broader social contexts.

This paper is based on fieldwork conducted in 2015 to 2016 in the two largest Salafi schools in Lombok Abu Hurairah and Assunnah. As a conceptual framework for analysis, I am utilizing social movement theory, particularly structural opportunity aspect. ${ }^{20}$ This theory is highly relevant because of both the rise of Salafism in the formal school setting, and resulting local social tensions, meet critical criteria for defining social movements involving aspects of political structure, cultural framing, and the mobilizing of social resources. This paper begins with a brief description of the history of the Salafi in Lombok and the theological and social doctrine of Salafism before exploring how Salafists have leveraged state recognition in promoting and disseminating their ideologies to generation in Lombok. The final section considers the impact of Salafist growth in fostering local social tensions.

\section{'Islam Sasak' and the Presence of Salafi}

Islamic practices and understanding among the Sasak community (local Lombok people) are diverse. It is evidenced by the presence of a range of different religious organizations among local Muslims such as Salafi group, Nabdlatul Wathan (NW), Nabdlatul Ulama (NU), Mubammadiyah, Hidayatullah, Tarbiyah Islamiyah, Lembaga Dakwah Islamiyah Indonesia (LDII),

${ }^{20}$ Quintan Wiktorowicz, "Islamic Activism and Social Movement Theory: A New Direction for Research," Mediterranean Politics 7, no. 3 (September 2002): 187-211; Glenn E. Robinson, "Hamas as Social Movement," in Islamic Activism and Social Movement Theory A Social Movement Theory Approach, ed. Quintan Wiktorowicz (Bloomington: Indiana University Press, 2004), 116. 
and Dewan Masjid Indonesia. ${ }^{21}$ These groups have institutional and ideological differences including the patterns of religiosity and tend to compete for the influence of adherents. Muslims in Lombok are dynamic groups, despite traditionalists being dominant, and their religious outlook expression is far from statistic both in the past and in the present.

Islam came to Lombok around the 16th century.22 Sasak people embraced boda, a ritual-ceremonial complex based on composite elements of animism, dynamism, and anthropomorphism. The worship of ancestral spirits and various other deities were the main focus. ${ }^{23}$ This pattern metamorphosed into Islam Wetu telu, a local expression of Islam which combined beliefs of Animism of Hinduism with Islam. ${ }^{24}$ Bartholomew suggests a pattern of religiosity that integrated longstanding Austronesian ideas with those Islam. Over times, the practices of the $W$ etu telu and the Boda have decreased in the face of increasing infiltration of outside influences, especially more orthodox forms of Islam. ${ }^{25}$ Nowadays Muslim in Lombok comprises $96.4 \%$ of the population compared to Hindus $2.5 \%$, Buddhist $0.5 \%$, and Christian $0.6 \%{ }^{26}$

Salafi is one of the new Islamic religious groups or sects that have established a presence in Lombok. They first arrived on the island during the $1990 \mathrm{~s}$, though there is no clear evidence concerning the early history of the Salafi movement there. The

${ }^{21}$ Erni Budiwanti, "The Purification Movement in Bayan, North Lombok Orthodox Islam Vis-à-Vis Religious Syncretism," in Between Harmony and Discrimination Negotiating Religious Identities within Majority-Minority Relationship in Bali and Lombok, ed. Brigitta Hauser-Schaublin and David D. Harnish (Leiden, Boston: Brill, 2014), 144-162; Erni Budiwanti, Islam Sasak Wetu Telu versus Waktu Lima (Yogyakarta: LKiS, 2000).

${ }^{22}$ Sven Cederroth, The Spell of the Ancestors and the Power of Mekekab: A Sasak Community on Lombok (Sweden: Acta Universitatis Gothoburgensis, 1981), 32.

23Sudirman, Gumi Sasak dalam Sejarah Bagian I (Lombok: KSU Primaguna-Pusat Studi dan Kajian Budaya, 2012); Cederroth, The Spell of the Ancestors, 32-33.

24Budiwanti, Islam Sasak, 139-195.

25John Ryan Bartholomew, Alif Lam Mim Kearifan Masyarakat Sasak. Transliter Imron Rosyidi (Yogyakarta: Tiara Wacana, 2001), 95.

26Badan Statistik NTB, Nusa Tenggara Barat dalam Angka Tabun 2013. 
lack of evidence might be caused by the movement which was not organized structurally compare to NU and NW. According to local Salafi leaders, Salafism was introduced first by Tuan Guru Husni in 1989 in Bagek Nyake, East Lombok after graduating from Madinah University, Saudi Arabia. ${ }^{27}$ In 1990, Tuan Guru Husni succeeded in taking over the Madrasah Al-Manar which had long been managed by his father Tuan Guru Abdul Manan, one of the local leaders of NU. Since the Madrasah has been led by Tuan Guru Husni, the ideological orientations have changed from traditionalism to Salafism. Through this school, he had been highly successful in reproducing new Salafi cadres to the point of posing a new challenge for the traditionalist Islam in Lombok.

\section{Theological and Social Doctrines of Salafism}

The main theological doctrine of Salafism is known within the movement as manhaj salaf (methodology of Salaf). Salafists state that the manhaj salaf represents an authentic understanding or 'pure' form of Islam, sourced directly from the Quran, Sunnah (prophetic tradition), and particularly to the earliest generations of Muslims. They are well-known amongst Muslim as al-salaf alsălih (righteous predecessors, - which includes the prophet's Companions) or abl-hadith. ${ }^{28}$ It roots the term 'Salafi' used predominantly by members of the movement. The prominent figure of Salafism as a religious movement in the mid-eighteenth century Saudi Arabia was Muhammad bin 'Abd al-Wahhāb. Then, the movement is often labeled as Wahhabism by outsiders.

Salafi represents one of the most prominent contemporary examples of a Muslim movement asserting the need for purification of contemporary understandings and practices of Islam in Indonesia. They perceive Islamic practice among widespread and established Muslim groups as being distorted by 2015.

${ }^{27}$ Interview with H. Abdullah, the head of Assunnah School, March 2,

${ }^{28}$ Adis Duderija, "Constructing the Religious Self and the Other: NeoTraditional Salafi Manhaj," Islam and Christian-Muslim Relations 21, no. 1 (January 2010): 77. 
syncretism (shirk, polytheism) and erroneous innovations (bid'ah). ${ }^{29}$ Bid'ah issue is not only a theological term among Abu Hurairah and Assunnah schools, but sociologically it acts as a form of challenge or negation to the legitimacy of other mainstream groups. It frequently links to claims of truth and salvation that oppose incorporation of aspects of local culture and tradition into religious practices of NU and NW. The use of the term bid'ah sharply distinguishes the Salafists from other groups. For this hadith of the Prophet: man 'amila 'amalan laysa 'alaybi amruna fabuwa raddun, Salafists groups argue that their views represent the pure Islam or uncorrupted form of Islam..$^{30}$

Their argument emerges theologically from particular approaches used by Salafist's scholars to understand Islamic doctrine. Firstly, Salafists reject philosophical or rational approaches to understanding Islam. ${ }^{31}$ They argue that the capacity of 'aql (rationality) is very limited and should refer to wabyu (revelatory text) as authoritative. ${ }^{32}$ Secondly, Salafi emphases the supremacy of texts associated with the prophet tradition. According to Duderija, Salafi scholarship is characterized by de-contextualization, a textual approach that hermeneutically neglects asbāb al-nu₹̄̄l (Qur'anic revelation background), ethical-moral and values based dimensions of the Quran and Sunna. Salafism is labeled a conservative or literalist sect. ${ }^{33}$ Salafi is in contrast with most mainstream Muslim groups

${ }^{29}$ Term bid'ah literally has two basic Arabic words, al-bad'u and al-ibda' which both have the same meaning: something happen without an example before or something new. Bid'ah terminology is an Islamic practice that it is perceived as something new which is not mentioned on Quran and Sunnah.'Abd al-Razāk al-Dāwish, Fatāwā al-Lajnah al-Rā'ah Li al-bubüthi alTlmiyyah wa al-Iftä, Second book. (Riyadh: Dār bi al-Nasiyah li al-Nashr wa al-Taw zi, 1317); al-Sihīimì, Kun Salafíyyan, 91-92.

30Meaning: "those who are doing some things out of the order are rejected". Strengthened by a hadith كل محدثة بدعة وكل بدعة ضلالة meaning: "every erroneous innovation is bid'ah, and every bid'ah is misguided". al-'Aql, Islämiyyah Là Wabäbìyah, 143; al-Sị̣īmìy, Kun Salafixyyan, 95.

${ }^{31}$ Muhammad 'Imārah, Thayyārat Al-Fiker Al-Islämì (Cairo: Dār alShurūq, 1995), 254.

${ }^{32}$ Robert W. Hefner, Making Modern Muslim the Politic of Islamic Education in Southeast Asia (Haw ai: University of Hawai Press, 2009), 87.

${ }^{33}$ Duderija, "Constructing the Religious," 78. 
which apply philosophical and contextual approaches to understand Islam.

In contemporary Lombok, many Salafist perspectives are opposite to those promulgated by mainstream or traditionalist Muslim organizations, particularly NU and NW which have incorporated aspects of local culture and local tradition in their religious expressions over a long period. Salafi scholars condemn all religious activity not mentioned in the Quran and Prophet Tradition as shirk and bid'ah. Mizan Qudsiah, who teaches Manbaj Salaf subjects in Abu Hurairah and Assunnah School states that the term bid'ah refers to a method which is purposely created in practicing Islamic doctrine with the intention of excessive in worshiping God. This method contradicts with the sharia which has finally been established". ${ }^{34}$ In practical terms, this involves opposing widespread forms of Islamic ritual which have long been accepted among the Sasak tribes in Lombok. The Islamic rituals are ziarah kubur (seeking intercession at graves), Maulid (celebrating prophet birthday), tablilan (praying for a person who has died by group recitation of Quran and other forms of prayer) and others local Islamic rituals. As a result, Salafi is often labeled as a puritanical group by traditionalist Muslims.

Salafi also has social doctrines that aim to strengthen the movement. Firstly, that of al-walà' wa al-barā' (unity and cutting off relationship), which gives particular emphasis to personal piety and unity within Muslim community and prohibits the students and the followers not to give their loyalty to nonMuslims. ${ }^{35}$ This doctrine can support persistent conflict between Muslims and non-Muslims. ${ }^{36}$ Secondly, ḩazr wa altaḥdhir or strengthening unity within the Salafi group and staying

${ }^{34}$ Mizan Qudsiyah, Kaidah-Kaidah Penting Mengamalkan Sunnah (Jakarta: Pustaka Imam Syafi'i, 2013), 37; al-Dāwish, Fatāwà al-Lajnah, 462-464.

${ }^{35} \mathrm{~W}$ ala ' is keeping a strong tie to pity people with affecting, helping them from their enemies, and living together with them. Bara $a^{\prime}$ is cut off relationships with disbelievers by hating them, not giving them a help, and staying away from them. More detail see Maha al-Bunyan, Al-Wala' wal Bara' Cinta dan Benci Karena Allah (Pustaka Ibnu Umar, 2014); Duderija, "Constructing the Religious," 86; al-Dāwish, Fatāwà al-Lajnah, 64-134; MA Plus Abu Hurairah, "Al-Wala wa al-Bara," Media Madrasah, June 2014.

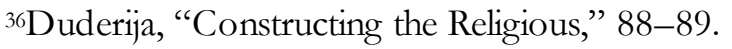


away from any religious activities of the abl al-bid'ah (people who incorporated culture and local traditions in their Islamic rituals and religious activity). It includes regular forms of religious practice among members of NU and NW. Thirdly, that of hazr, advising their students and followers to cut off relationships and stay away from both groups, non-Muslims and abl al-bid'ah. ${ }^{37}$ Qudsiah argued that based on manhaj salaf principles, members of Salafi groups are expected to detest, be unsympathetic and uncooperative with the practices of the abl al-bid'ah. These principles should be followed as a way to preserve pure Islamic understanding from any modifications that can cause anxiety and weaken aqidah (belief in God). Seeking Islamic knowledge from such groups is forbidden. ${ }^{38}$ It is also an influence from the Salafi value of ittiba,', (obedience), which suggests that following the prophet traditions is not only being submissive to His tradition, but also means both avoiding the bid'ah and practicing taḥdhir (cut off relationship against the abl al-bid'ab). ${ }^{39}$ Fourthly, Salafi also denounces tashabbuh (imitation of disbelievers) which refers to similarities with Western culture and traditions such as singing, playing and hearing secular or popular music, social interactions between men and women without relationships as understood in rigid religious-legal terms, prohibiting women from working outside of their home, and so on. In this sense, Salafist has also been labeled a form of Islamism - in the sense of a reordering of society in strict accordance with a particular view of what constitutes Shariah.

Salafist are well-known in Lombok and Indonesia by typical fashion or conservative form of dresses. Salafi women in public are strictly enjoyed wearing the niqab (face-veiling). Men must lengthen their beard and adopt the use of white turbans, galabiya (long robes), and isbal (trousers cut at the ankle) in daily life. Gunawan, a Salafi leader in Lombok and head of Abu Hurairah high school states that these strict features are practiced as a

${ }^{37}$ Qudsiyah, Kaidah-Kaidah, 51.

${ }^{38} \mathrm{Ibid}$., 50; see also MA Plus Abu Hurairah, Media Madrasah, December 2013.

${ }^{39}$ al-Sihīimìy, Kun Salafiyyan, 99-100; al-'Aql, Islämiyyah Là Wabäbiyyah, 359. 
form of obeying the sunnah. All practices done by the Prophet should be maintained and obeyed, including fashion aesthetics. The fashion aesthetics are not a just optional doctrine but an obligation for every Muslim. ${ }^{40}$

Despite majority mainstream Muslim groups in Lombok attempting to portray Salafism as dangerous fanatics with exclusive doctrines, Salafism has been growing steadily over the last few decades. In its first ten years, from 1990 to 2002 most people were unaware of its existence, and there was little growth in the movement. But over the past ten years, from around 2002 to 2016, Salafism has experienced significant local growth, reflected in the increasing number of Salafi schools and mosques established and the growing number of followers and students in its schools. This expansion in enrollment has occurred following the official integration of these schools into the Indonesian national education system. By becoming the formal schools both Abu Hurairah School and Assunnah School more well-known by the local people.

\section{State Recognition: A Structural Opportunity}

In addition to carrying out the usual dakwah activities, in the early 2000s Salafist in Lombok shift strategy from non-official to official education to gain state recognition and support for sustainable institution building. From 2000 to 2006, Yayasan Abu Hurairab (Abu Hurairah Foundation) in Mataram has successfully established formal educational institutions at various levels and types such as Madrasah Aliyah Plus (high school), Sekolah Menengah Pertama Islam Terpadu (elementary school), Sekolah Dasar Islam Terpadu (primary school) and Ma'ahad Aly (religious diploma). Similar to Abu Hurairah, Yayasan Assunnah, the Assunnah Foundation in East of Lombok has been offering the same formal schooling in various levels and types. The use of the label, Islam Terpadu (Integrated Islamic school) and madrasah plus are one feature of the Salafi schools. These provided an impression that the Salafi School holds advantages

${ }^{40}$ Interview with Gunawan, the head of Abu Hurairah School, October 16, 2015. See also Tabloid Al-Furqon Edisi I tahun 1425, 29-33. 
compared to Islamic schools in general. It is through these schools the Salafism increasingly gains support from local people and government in Lombok.

By integrating its schools into the national education system, Salafi schools do have to accept some consequences as well as advantages. Salafi schools have had to accept the government curriculum for non-Islamic subjects and abide by aspects of government regulation of education. According to 2003 National Education System Law, every formal school has to offer at least 12 non-religious subjects (see curriculum 2013 for SD/MI, SMP/MTs and SMA/MA). But Salafi schools have gained legitimacy as formal schools institutions which cater to the need of local people and financial support from the government. This legitimacy is practically important and strategic as a response to the local people's aspirations for official certificates in order to access higher education and a career. According to Gunawan, the head of the Abu Hurairah School, "the main reasons for developing a formal school is public demand. People perceived that educational institutions which focused on religion without formal schooling do not offer future opportunities to pursue a career." 41

By formalizing their status, Salafi Schools receive forms of state funding. In 2015 for instance, through the program Bantuan Operasional Sekolah (School operational funding). ${ }^{42}$ Both Abu Hurairah schools on average received IDR. 1.898.180.000 (AUD\$190.000) and Assunnah received IDR. 791.800.000 (AUD\$790.000) per year. The funding is based on the number of students in each school level. Likewise, there are other kinds of the government programs that can be accessed by the Salafi Schools, such as Bantuan Siswa Miskin (a scholarship program for the impoverished student), and Sertifikasi Guru (allowances for teachers).

Moreover, as a result of becoming recognized formally in the state system, Salafi religious schools began to receive official

${ }^{41}$ Interview with Gunawan, October 5, 2015.

42"Pedoman Bantuan Operasional Sekolah 2013" (Kementerian Pendidikan dan Kebudayaan, 2013); "Pedoman Bantuan Operasional Sekolah 2016" (Kementerian Pendidikan dan Kebudayaan, 2016). 
invitations for Arabic speech, preaching (dakwah) and al-Qur'an memorizing competitions organized by regional and national levels of government. These competitions are highly regarded in Lombok, attracting a large amount of public attention and respect for the best performers. The competitions present a significant opportunity for Salafi schools to promote the ability of their students in areas that have long been a part of the main program of education in their schools, and Salafi students are in fact very successful in the competitions, quite often winning them. In 2016 for instance, two Abu Hurairah students represented West of Nusa Tenggara (NTB) province to the Arabic speech competition at the national level after winning regional level. The same feat was performed by an Assunnah school student, who was a runner-up in the Islamic religious speech competition in NTB province in 2015. As a direct result, the schools began to become more widely known and more well-regarded by local people. These competitions have provided to be instruments in generating a popular reputation for Salafi schools as providing high-quality and strong religious knowledge; this remains a widespread perception among people in Lombok, even when little else is known about the Salafi doctrines.

The achievements above are highly relevant to understand why Sasak people have chosen Salafist schools to educate their children. Indeed, it is possible to categorize local people's expectation for choosing a Salafi school into two cases, religious and pragmatic. In regard to the religious, Sasak people perceive Salafi schools as offering advanced training in memorizing the Quran (Tahfiz al-Qur'an) and in learning Arabic speech and preaching skills, all of which have long been regarded as providing an individual with powerful religious merit including great facilitating entry to heaven in the hereafter. Fluency in Arabic is itself considered a source of significant blessing (pahala), as the language of God and prophet, and forms a source of considerable respect and status among local communities in Lombok, particularly in matters of religious tradition. Salafi schools have a much stronger emphasis on these capabilities compared to mainstream Islamic schools as 
demonstrated in competitions. Moreover, this has had an effect in Sasak people perceiving the Salafi group as having strong religious commitments which they believe may offer a solution for moral concerns regarding the behavior of their teenagers in modern life.

Participating and succeeding in these kinds of competitions are a strong indication that Salafi groups are engaging in Islamic traditions that are meaningful and significant in local terms. On the basis of its theological and social doctrines, this problematizes the dominant view among scholars of Salafism as an exclusive and inflexible Puritan group that rejects the incorporation of local tradition or flexibility in Islamic practices. In Lombok context, Salafi groups have selectively incorporated locally relevant Islamic traditions that relate broadly to Muslim people rather than the local traditions. Arabic speech, memorizing the Quran, and preaching skills are the great traditions for Muslim people in general. Despite there is no available a verses in the Quran and Sunnah suggest on competing them, nevertheless these are believed to be an extremely important part of the promotion of manhaj salaf. However, the inclusion of the ideas is in opposition to the Salafi theological doctrine itself. 43

In terms of pragmatic reasons, many Muslim in Lombok have relatively low incomes and struggle to reach a reasonable standard of living. Parents view formal schooling as means to pursue aspirations for their children to gain a well-paid career (and provide for them in the future). In addition, there are specific Middle Eastern scholarships available to students at Salafi schools. In 2016, for instance, there are sixty Abu Hurairah alumni who are studying at LIPIA University, five at Madinah and twelve teachers at some Indonesian Universities by Middle Eastern scholarships. ${ }^{44}$ Many parents lack the income to be able to provide higher education for their children, so the availability of theses scholarships is also very attractive.

${ }^{43}$ Compering to Qudsiyah, Kaidab-Kaidab; al-Sihịmīy, Kun Salafiyyan.

${ }^{44}$ Interview with Tomy, a leader of Abu Hurairah schools, December 27, 2016. 
Salafi group in Lombok has gained considerable influence among the local community by using structural opportunities thereby greatly increasing its local followers. Salafi has been able to leverage the 'Indonesian political will" through its formal schools resulting in a strengthening of the movement. Referring to the Robinson concept, the structural opportunity is an important aspect in the social movements. ${ }^{45}$ As one of the religious social movements, Salafi needs it in order to expand its acceptance. This aspect is overlooked by some scholars who tend to argue that the Middle Eastern support as the main factor that influenced the increasing number of the Salafi members. According to Chaplin's research of Salafism in Yogyakarta, Saudi Arabia has an important role not only ideologically, as the source of religious authority and social ideal, but also financially, as a source of financial support for educational institutions and Salafi groups in Indonesia. ${ }^{46}$ Similarly, Liow shows that the development of Salafism in Thailand has long been supported by Middle Eastern governments particularly Saudi Arabia, Kuwait, and Qatar. This leads to the establishment of a number of non-governmental institutions such as Muassasab of the United Arab Emirates, Saudi-based Rabitah Islam, Qatar's Jamiyyah al-Hilal lid-Dirasat wa-Tanmiyah (Hilal Association for Education and Development), and Jamiyyah Ibya al-Turath AlIslami involved in the effort to promote Salafism in Thailand. ${ }^{47}$

I acknowledge that the Salafi movement, as elsewhere, has long had transnational networks in particular with Saudi Arabia, which offers sources of financial support as well as training and expertise for teachers, preachers, and students. But in my view, local factors have been much important in bolstering the growth of the Salafi movement in Lombok rather than the Middle Eastern supports. And Salafi groups have actively sought to engage with local factors to this end. One firm indication of this is the groups' involvement in the kinds of Islamic religious competitions mentioned previously. The existing literatures e.g.

\footnotetext{
45Wiktorowicz, "Islamic Activism and Social Movement Theory," 15; Robinson, "Hamas as Social," 116.

${ }^{46}$ Chaplin, "Imagining the Land," 217.

47Liow, "Muslim Identity," 383-421.
} 
Wright, ${ }^{48}$ Chaplin,${ }^{49}$ Liow, ${ }^{50}$ Meuleman, ${ }^{51}$ Noorhaidi, ${ }^{52}$ and Wiktorowicz, ${ }^{53}$ depicts Salafism strongly as an exclusive and puritan group that rejects the incorporation of tradition and any notion of flexibility in Islamic practices, as a result of emphasizing the theological and social doctrines of Salafi groups. However, in Lombok context, I argue that Salafi group have selectively incorporated aspects of non-doctrinal Islamic traditions in Lombok that might be considered broadly shared among Muslims in Indonesia and elsewhere in the Muslim world, while at the same time avoiding specifically local traditions of religious practice. Arabic fluency, Quranic memorization, and skills in preaching oratory are among these broad traditions. Despite the absence of any verses in the Quran or Sunnah that relate to engaging in competitions in these areas, nevertheless, they are perceived by Salafi in Lombok as playing an extremely important in the promotion of manhaj salaf. Nonetheless, the inclusion of these practices might be viewed as inconsistent with Salafi theological doctrine.

Similarly, the reliance of Salafi schools in Lombok on engaging the Indonesian State and attracting government support contrast with Salafist group in other setting, e.g. Liow's in Thailand and Wiktorowicz in Jordan where the movement seeks to distance itself from the state and relying on informal networks to promote Salafism through forms of non-state education. ${ }^{54}$ Moving to state education system, as Salafi has done, is generally Islamic education in inclination in Indonesia. This strategy already has been used by the Islamic groups such

\footnotetext{
${ }^{48}$ Wright, "Salafi Theology and Islamic Orthodoxy in West Africa."

${ }^{49}$ Chaplin, "Imagining the Land."

50Liow, "Muslim Identity."

51Meuleman, "Dakwah."

${ }^{52}$ Hasan, "The Salafi."

53Wiktorowicz, "Anatomy of the Salafi."

${ }^{54}$ Note that both Jordan and Thailand involve contexts of potential or actual state repression. Wiktorowicz argues that the Salafist in Jordan decided to keep distance from the state to avoid such repression and have been growing steadily as a result relying on their informal social network with the Middle East, even without the support of the local government. Wiktorowicz, "Islamic Activism and Social Movement Theory," 22.
} 
as NU, Muhammadiyah, Persis, NW, and others. ${ }^{55}$ They have integrated into the national education system to gain state recognition and support for the sustainability of their institution. By offering the formal schools, Salafi is viewed as a group which is catering a social need and expectation.

\section{Disseminating Salafism in Formal School Setting}

Despite Salafi schools in Lombok incorporate into the state education system, Salafi continues to insist on offering ideological doctrines in its formal schools. Dissemination of ideology is occurring in all aspects of the formal education the schools provide. This took the three field forms of core-extrabidden curriculum, which featured in the textbook and religious sources, as well as among teachers and student organizations. In the core-curriculum for instance, there is a specific subject Manhaj which embeds the ideological-theological doctrines of Salafism on all of the levels of the schools. This subject is as an umbrella of the all religious subjects which provide the theological and social doctrine of Salafism. Supporting the Manhaj subject, there are at least 13 other religious subjects comprising more than 40 hours per a week. Ideologically, these subjects play a critical role in constructing what Apple refer to as a normative concept in the legitimation of culture through the curriculum. ${ }^{56}$ The position of the Islamic group has a much stronger control over this dimension of formal schooling than the state authority.

The religious textbooks in use have strongly ideological, even biased content. The content is not only concerned with

55Florian Fohl, "Negotiating Religious and National Identitities in Contemporary Indonesia Islamic Education," Cross Currents 61, no. 3 (2011): 399-414; Azyumardi Azra, Dina Afrianty, and Robert W. Hefner, "Pesantren and Madrasah: Muslim Schools and National Ideals in Indonesia," in Schooling Islam the Culture and Politics of Modern Muslim Education, ed. Robert W. Hefner and Muhammad Qosim Zaman (New Jersey: Princeton University Press, 2007), 187; Muhammad Zuhdi, "The 1975 Three-Minister Decree and the Modernization of Indonesian Islamic Schools," American Educational History Journal 32, no. 1 (2005): 36-43.

${ }^{56}$ Michael W Apple, Ideology and Curriculum (New York: Taylor and Francis e-Lebrary, 2002), 82. 
reproducing the core truth and salvation claims of Salafism but also direct strong theological criticism toward the ritual of many mainstream groups. All religious textbooks and other kinds of academic religious sources are taken from the Saudi Arabia Ministry of Education. Indeed, Saudi Arabia has an important ideological role as the source of religious authority and social ideal for educational institutions among Salafi groups in Indonesia. ${ }^{57}$ Being easy to understand, Arab Saudi has translated more than a million Arabic religious books to Indonesian language and published them over all Salafi schools across the island. ${ }^{58}$

Salafi schools also provide extra-curricular and student association programs in further promoting its ideology. The extra-curriculum consists of religious activities such as dawrah $d u^{\prime a t}$ (preaching training), Arabic speech, tabfic al-Qur'àn (memorizing Quran), dawrah akbläq (behavior training), and other religious training and rituals. Note that, tahfiza al-Qur'an is also included in the core curriculum. Likewise, OSIP (Organisasi Santri Pondok), the Salafi student association takes part in promoting manhaj salaf in many kinds of ideological activities and rituals within the schools. The board member of this association has an important role in controlling daily activities all of the students.

Additionally, the role of teachers and other staff in the Salafi schools can be considered as an 'ideological apparatuses'59 in the sense of promoting the manhaj salaf in the formal school. Indeed, teaching staff is chosen based on ideological considerations, notably, the form of Muslim identity they express. In the internal guidelines of education within Abu Hurairah school, for instance, recruitment of teachers and staff involve specific procedures and requirements. A person who wants to be a teacher must obtain tazkiyah (recommendation) from one of the Salafi preachers and he approved by Dewan Istishari (shar'iyah

${ }^{57}$ Chaplin, "Imagining the Land," 217.

${ }^{58}$ Angel M Rabasa, "Islamic Education in Southeast Asia," Current Trends in Islamist Ideology 2 (2005): 97-109.

${ }^{59}$ Louis Althusser, On the Reproduction of Capitalism Ideology and Ideological State Apparatuses (London: Verso, 1971). 
council). ${ }^{60}$ Before approving, the prospective teachers have an interview which focuses on their understanding of religious matters based on manbaj salaf. These two requirements are seen as ensuring that teaching staff have appropriate ideological understandings and ready to embed Salafism at the schools ${ }^{61}$. The teaching staff at both Abu Hurairah and Assunnah schools are dominated by alumni from LIPIA and Ibn Sa'ud Islamic University of Madinah. LIPIA is the branch of the Arab Saudis Ibn Sa'ud Islamic University in Indonesia. In Abu Hurairah High School, for instance, there are 24 religious teachers; 23 of these are alumni of both institutions. ${ }^{62}$ The OSIP is also that has been involved in carrying religious programs and directing overall daily activities of students, particularly in the implementation and maintenance of the Salafi doctrine. ${ }^{63}$

Thus, the teachers provide and support ideological perspectives on religious matters that arguably indoctrinate rather than inspiring young people to explore for themselves pathways to understanding Islam. In this condition, the education primarily should reflect the needs of the society, but in fact, it must 'stopped one's head to ideology' 64 and allowed the ideology to maintain and control for the sake of hegemony ${ }^{65}$ on Islamic understanding, religious authority and Islamic group competition. Otherwise, it tends to maintain social fragmentation and potentially threaten to undermine social cohesion. That means the integration is not only motivated by modernization force, social expectation and government financial support as Steenbrink, Hefner, and Azra have argued. But it also is influenced by ideological aims or expectations. Steenbrink and Azra argue that the integration of Islamic schools into the national education system in Indonesia is a

60Ponpes Abu Hurairah, "Pedoman Pendidikan Abu Hurairah 2016," n.d., 36 .

61Interview with Gunawan, September 9, 2015.

${ }^{62} \mathrm{MA}$ Plus Abu Hurairah, "Daftar Guru Tetap MA Plus Abu Hurairah Mataram Tahun Pelajaran 2014/2015," n.d.

${ }^{63}$ MA Plus Abu Huraiah, Media Madrasah 3, Desember 2013.

${ }^{64}$ H.A.R. Tilaar, Kekuasaan dan Pendidikan, Manajemen Pendidikan Nasional dalam Pusaran Kekuasaan (Jakarta: Rineka Cipta, 2009), 177.

${ }^{65}$ Apple, Ideology and Curriculum, 82. 
response among Muslim people to the challenges of modernization. People view formal schooling as means to pursue aspirations for their children to gain a well-paid career, and in addition to gaining financial support from the government. ${ }^{66}$ But little attention has been given to the ideological aims or expectations of the groups concerned. This is despite the importance of this dimension as a key element in shaping the features and qualities of the schools concerned, as well as its potential for negative impacts on local Muslim communities, such as fostering social tensions through sectarian fragmentation.

\section{Responding to Salafism: Local Social Tensions}

Puritanical doctrines and attitudes embedded in various aspects of education, brought Salafi's students, alumni and followers in resistances and sectarian strives in the social and religious life. Salafists use the issues of proper understanding and religious purification as an ideological tool to promote and maintain their doctrines and identities to attack traditionalist Muslim groups. Salafism represents one of the most prominent contemporary examples in asserting that they have to purify the contemporary understandings and practices of Islam in Lombok, which they perceive have been distorted by syncretism (shirk, polytheism) and erroneous innovations (bid'ah) among more widespread and established Muslim groups. Labeling shirk and bid'ah on local Islamic traditions are the main issues that caused social fragmentations and local reactions. Expanding it ideological struggle into the formal school system has contributed to increasing local fragmentation of theological interpretations, which in turn has led to a fierce local tension in Lombok. I argue that the differences of interpretation on religious doctrines and practices between Salafists and mainstream Muslim groups which are followed by truth and

${ }^{6} 6$ Karel A. Steenbrink, Pesantren Madrasah dan Sekolah Pendidikan Islam Kurun Modern, 2nd ed. (Jakarta: LP3ES, 1994); Azyumardi Azra and Jamhari, "Pendidikan Islam Indonesia dan Tantangan Globalisasi: Perspektif SosioHistoris," in Mencetak Muslim Modern Peta Pendidikan Islam di Indonesia, ed. Jajat Burhanudin and Dina Afrianty (Jakarta: RajaGrafindo Persada, 2006), 4. 
salvation claims, and the struggling of Islamic authority have caused a major source of this local social tension.

Mainstream Muslims perceive that the proliferation of Salafist doctrine has been undermining local patterns of religiosity which has long been practiced by local people. Truth, salvation claims, and the label misguided of bid'ah and dalalah are seen as a view that encourages hate and violence between Muslims. Scholars examining the impact of Salafism elsewhere in Indonesia suggest that the theological and textual approach of Salafism provide major sources of religious conflict between Salafi and mainstream groups. ${ }^{67}$ In Lombok, I have documented 12 conflicts between 2004 to 2015 in which Salafists or Salafi school has played a key role. In 2016 in Wanasaba in East of Lombok, a Salafi mosque was destroyed. In June 2015 in Batukliang, a district in Center of Lombok eight Salafist houses was destroyed by traditionalist members. Similarly, in February 2009 in Gunungsari, a district in West of Lombok, there were 15 Salafists have been evacuated. Their houses were destroyed and they were the target of threats to expel them from the village.

Beyond local reactions to Salafi ideas, such conflicts can also be understood as a means by which the traditionalist group acts to maintain its domination in public sphere. Since Salafi become established in the 1990s, some NW and NU members have converted to the movement, and several become Salafist preachers. H. Mahsun and H. Said, two famous Salafi preachers both graduated from a NW Pesantren (Islamic boarding school). After becoming a Salafi preacher, Mahsun had been expelled from his village. ${ }^{68}$ Similarly, in $2006 \mathrm{H}$. Said's school Salafioriented, Sekolah Bani Shaleh was destroyed by traditionalist followers who represented him as 'a misguided preacher doctrine'. ${ }^{69}$ Former traditionalists have also experienced violence. H. Ihsan for instance, faced threats of being expelled

${ }^{67}$ Murdianto and Azwani, "Dakwah dan Konflik"; Faizah, "Pergulatan Teologi Salafi dalam Maenstream Keberagamaan Masyarakat Sasak"; Nuh and Mufid, "Kelompok Salafi"; Saparudin, Pemutusan Hubungan, 60-75.

${ }^{6}$ Interview with H. Mahsun, a Salafi prominent figure, January, 2013.

${ }^{6}$ Interview with H. Said, a Salafi prominent figure, October, 2015. 
from his village because he stopped taking part in tablilan (which he now considered bid'ab).

In response to these conflicts between Salafist and traditionalist Islam, Wahid Institut and Lensa Mataram, the two NGOs have held focus group discussions which focus on Salafi doctrine. The discussion recommended Salafist scholars to promote a moderate and tolerant perspective on Islamic proliferations and respect to each other. I believe that the potential for conflict in Lombok is significant. If the anti-Salafi sentiment and some other factors continue, more conflict is likely to occur.

\section{Conclusion}

Despite facing intense backlash and violence from traditionalist mainstream Muslims groups, Salafi schools and movement have increased steadily. By establishing the formal school, the number of Salafist movement has been able to expand and successfully promote its ideology. Salafism has gained acceptance among the local community by using structural opportunities and been able to attract local followers. By establishing certified national schools, Salafi groups in Lombok have found a way to recruit a new young generation of Muslims who are ready to run manhaj salaf, despite the movement fails to do so through dakwah conventional (conventional propagation).

Moreover, as a result of formal recognition in the state system, Salafi religious schools began to receive official invitations to Arabic speech, preaching (da'wab) and Quran memorizing competitions from regional and national levels of government, which represent the great Islamic traditions. The invitations to these prestigious events presented an opportunity to Salafi schools to show the ability of their students in areas that have long been a focus of the main program in their schools. Students from prominent Salafi schools have been very successful in the competitions, often winning them. As a result, the schools began to become more well-known and more wellregarded by local people. The competitions improved Salafi's reputation for Salafi schools as the provider of high-quality 
religious education. It remains a widespread perception among people in Lombok, even though detailed knowledge of Salafi doctrine is less common, particularly their perspectives viewing bid'ah of Sasak traditional religious practice. The Salafi educational institutions have become a new phenomenon in contemporary Islamic education in Lombo but this new success is also creating new worrying social tensions.

\section{References}

Althusser, Louis. On the Reproduction of Capitalism Ideology and Ideological State Apparatuses. London: Verso, 1971.

Alvi, Hayat. "The Diffusion of Intra-Islamic Violence and Terrorism: The Impact of the Proliferation of Salafi/Wahabi Ideologies." Middle East Review of International Affairs 18, no. 2 (Summer 2014): 38-50.

Apple, Michael W. Ideology and Curriculum. New York: Taylor and Francis e-Lebrary, 2002.

al-'Aql, Nāṣir bin 'Abd al-Karìm. Islāmiyyah Lā Wahābiyyah. Saudi: Dār al-Fadịlah, 2007.

Azra, Azyumardi, Dina Afrianty, and Robert W. Hefner. "Pesantren and Madrasah: Muslim Schools and National Ideals in Indonesia." In Schooling Islam the Culture and Politics of Modern Muslim Education, edited by Robert W. Hefner and Muhammad Qosim Zaman. New Jersey: Princeton University Press, 2007.

Azra, Azyumardi, and Jamhari. "Pendidikan Islam Indonesia dan Tantangan Globalisasi: Perspektif Sosio-Historis." In Mencetak Muslim Modern Peta Pendidikan Islam di Indonesia, edited by Jajat Burhanudin and Dina Afrianty. Jakarta: RajaGrafindo Persada, 2006.

Bartholomew, John Ryan. Alif Lam Mim Kearifan Masyarakat Sasak. Transliter Imron Rosyidi. Yogyakarta: Tiara Wacana, 2001.

Budiwanti, Erni. Islam Sasak Wetu Telu versus Waktu Lima. Yogyakarta: LKiS, 2000.

—. "The Purification Movement in Bayan, North Lombok Orthodox Islam Vis-à-Vis Religious Syncretism." In Between Harmony and Discrimination Negotiating Religious Identities within 
Majority-Minority Relationship in Bali and Lombok, edited by Brigitta Hauser-Schaublin and David D. Harnish, 144-162. Leiden, Boston: Brill, 2014.

al-Bunyan, Maha. Al-Wala' wal Bara' Cinta dan Benci Karena Allah. Pustaka Ibnu Umar, 2014.

Cederroth, Sven. The Spell of the Ancestors and the Power of Mekekah: A Sasak Community on Lombok. Sweden: Acta Universitatis Gothoburgensis, 1981.

Chaplin, Chris. "Imagining the Land of the Two Holy Mosques: The Social and Doctrinal Importance of Saudi Arabia in Indonesian Salafi Discourse." Austrian Journal of South-East Asian Studies 7, no. 2 (December 2014): 217-236.

al-Dāwish, 'Abd al-Razāk. Fatāwā al-Lajnah al-Rā'ah Li al-bubūthi al-Ilmiyyah wa al-Iftā. Second book. Riyadh: Dār bi al-Nasiyah li al-Nashr wa al-Tawzi, 1317.

Duderija, Adis. "Constructing the Religious Self and the Other: Neo-Traditional Salafi Manhaj." Islam and Christian-Muslim Relations 21, no. 1 (January 2010): 75-93.

Faizah. "Pergulatan Teologi Salafi dalam Maenstream

Keberagamaan Masyarakat Sasak." Ulumuna 16, no. 2 (December 2012): 375-402.

Fohl, Florian. "Negotiating Religious and National Identitities in Contemporary Indonesia Islamic Education." Cross Currents 61, no. 3 (2011): 399-414.

Hasan, Noorhaidi. "Salafi Madrasahs and Islamic Radicalism in Post-New Order Indonesia." In Islamic Studies and Islamic Education in Contemporary Southeast Asia, edited by Kamaruzzaman and Patrick Jory. Kuala Lumpur: Yayasan Ilmuan, 2011.

"The Salafi Madrasas of Indonesia." In The Madrasa in Asia Political Activism and Transnational Lingkages, edited by Farrish Noor, Yoginder Sikand, and Martin van Bruinessen. Amsterdam: Amsterdam University Press, 2007.

Hefner, Robert W. Making Modern Muslim the Politic of Islamic Education in Southeast Asia. Hawai: University of Hawai Press, 2009.

'Imārah, Muhammad. Thayyārat Al-Fiker Al-Islāmì. Cairo: Dār alShurūq, 1995. 
Liow, Joseph Chinyong. "Muslim Identity, Local Networks, and Transnational Islam in Thailand's Southern Border Provinces." Modern Asian Studies 45, no. 6 (2011): 13831421.

MA Plus Abu Hurairah. "Al-Wala wa al-Bara.” Media Madrasah, June 2014.

. "Daftar Guru Tetap MA Plus Abu Hurairah Mataram Tahun Pelajaran 2014/2015," n.d. Media Madrasah, December 2013.

Meuleman, Johan. "Dakwah, Competition for Authority, and Development." Bijdragen tot de taal-, land- en volkenkunde / Journal of the Humanities and Social Sciences of Southeast Asia 167, no. 2-3 (January 2011): 236-269.

Murdianto, and Azwani. "Dakwah dan Konflik Sosial Jama'ah Salafi di Gunungsari Lombok Barat." Jurnal Penelitian Keislaman 9, no. 2 (2013).

Nuh, Nuhrison M., and Ahmad Syafi'i Mufid. "Kelompok Salafi di Kabupaten Lombok Barat." In Kasus-Kasus Aliran/Pabam Kegamaan Aktual di Indonesia. Jakarta: Balitbangdiklat Depag, 2009.

Ponpes Abu Hurairah. "Pedoman Pendidikan Abu Hurairah 2016," n.d.

Qudsiyah, Mizan. Kaidah-Kaidah Penting Mengamalkan Sunnah. Jakarta: Pustaka Imam Syafi'i, 2013.

Rabasa, Angel M. "Islamic Education in Southeast Asia." Current Trends in Islamist Ideology 2 (2005): 97-109.

Robinson, Glenn E. "Hamas as Social Movement." In Islamic Activism and Social Movement Theory A Social Movement Theory Approach, edited by Quintan Wiktorowicz. Bloomington: Indiana University Press, 2004.

Saparudin. Pemutusan Hubungan Keluarga Berdasarkan Afiliasi Lembaga Keagamaan di Lombok. Timur. Laporan Penelitian Dosen Muda. DP2M Dikti, 2007.

al-Siḥ̄ì̄y, 'Abd al-Salām. Kun Salafiyyan 'Alā al-Jaddah. Madinah al-Nabawiyah, 1423.

Steenbrink, Karel A. Pesantren Madrasah dan Sekolah Pendidikan Islam Kurun Modern. 2nd ed. Jakarta: LP3ES, 1994. 
Sudirman. Gumi Sasak dalam Sejarah Bagian I. Lombok: KSU Primaguna-Pusat Studi dan Kajian Budaya, 2012.

Sukarnadi, Abdul Aziz. Di Bawah Lindungan Rasulullah Menyibak Tirai Keagungan Sang Manusia Cahaya. Yogyakarta: Aswaja Pressindo, 2015.

—. Perisai Ke-Aswaja-an Nabdlatul Wathan Membedah 17 Literatur Anti Wahabi Rekomendasi Pendiri NW. Yogyakarta: Samudera Biru, 2016.

Tilaar, H.A.R. Kekuasaan dan Pendidikan, Manajemen Pendidikan Nasional dalam Pusaran Kekuasaan. Jakarta: Rineka Cipta, 2009.

Wiktorowicz, Quintan. "Anatomy of the Salafi Movement." Studies in Conflict \& Terrorism 29, no. 3 (2006): 207-239.

- "Islamic Activism and Social Movement Theory: A New Direction for Research." Mediterranean Politics 7, no. 3 (September 2002): 187-211.

- "The Salafi Movement in Jordan." International Journal of Middle East Studies 32, no. 2 (May 2000): 219-240.

Wright, Zachary. "Salafi Theology and Islamic Orthodoxy in West Africa." Comparative Studies of South Asia, Africa and the Middle East 35, no. 3 (January 2015): 647-656.

Zuhdi, Muhammad. "The 1975 Three-Minister Decree and the Modernization of Indonesian Islamic Schools." American Educational History Journal 32, no. 1 (2005): 36-43.

"Pedoman Bantuan Operasional Sekolah 2013." Kementerian Pendidikan dan Kebudayaan, 2013.

"Pedoman Bantuan Operasional Sekolah 2016." Kementerian Pendidikan dan Kebudayaan, 2016. 